\title{
PERLINDUNGAN HAK PATEN
}

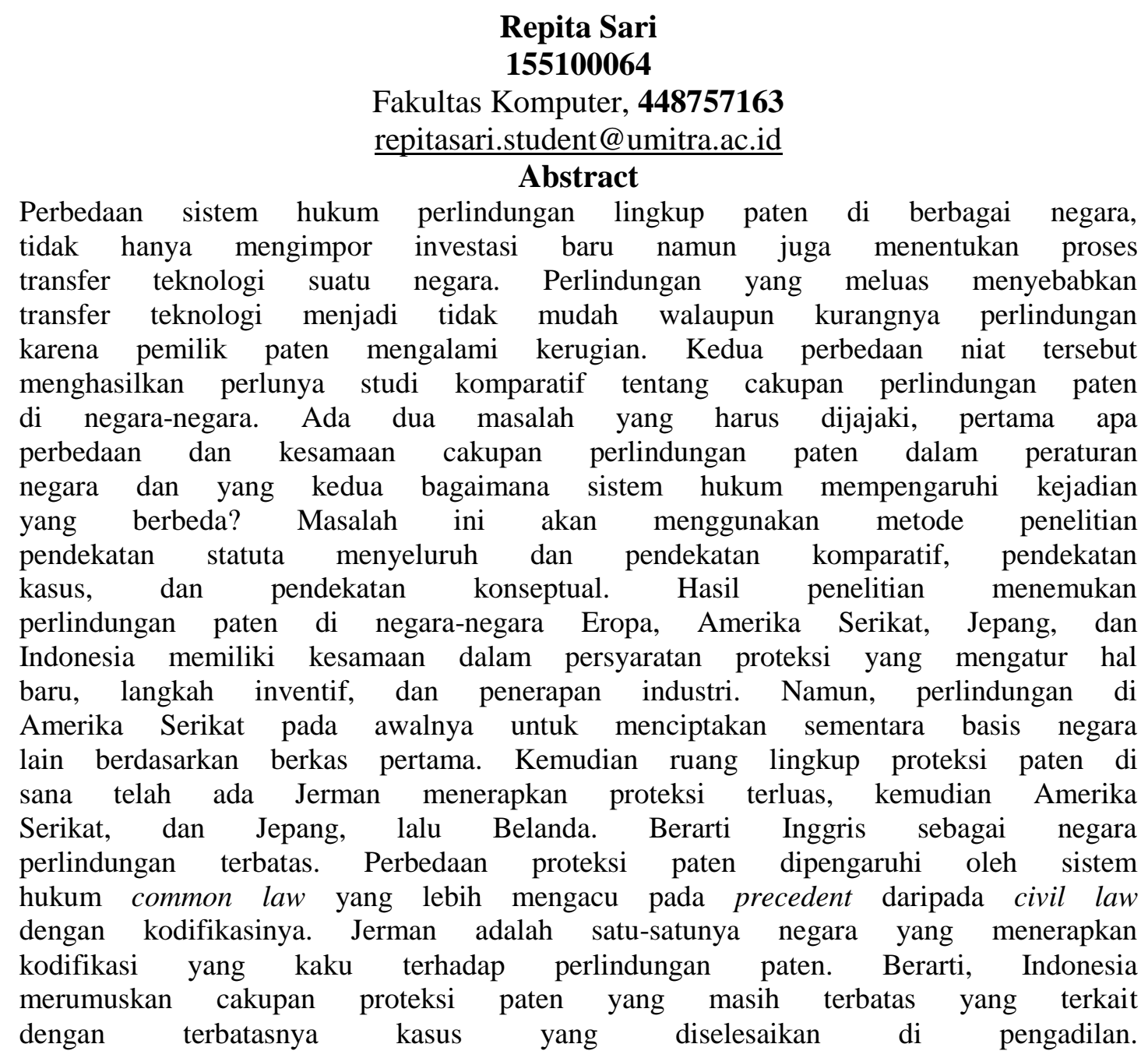

Kata Kunci : Hak Paten, Perlindungan Ruang Lingkup, Hukum Komparatif

\section{A. INTRODUCTION}

Perkembangan teknologi suatu negara, tidak lepas dari aspek perlindungan hak paten yang berlaku pada negara tersebut. Negara Jepang sebagai contoh, adalah negara yang dikenal paling maju teknologinya.

Semula negara ini banyak mencontoh teknologi negaranegara Eropa dan 
Amerika, namun dalam perkembangan yang kita ketahui akhir-akhir ini justru Jepang-lah yang menjadi kiblat dari negara-negara lain termasuk

Eropa dan Amerika. Dalam perlindungan hak paten, apabila lingkup perlindungan yang

diberikan terlalu luas kepada pemegang hak paten, maka sistem perlindungan hukum tersebut berdampak pada proteksi hak paten yang dipegang oleh seseorang menjadi sangat kuat, namun proses alih teknologi

pada negara tersebut tidak mudah terjadi, sebab modifikasi yang tidak

Fiat Justisia Jurnal Ilmu Hukum ISSN 19785186

Volume 10 Number 4, October-December 2016 699

substansial pun dari pihak lain masih bisa dinilai sebagai pelanggaran hak paten. Sebaliknya apabila perlindungan yang diberikan kepada pemegang hak paten terlalu sempit, maka pemegang hak paten mudah dirugikan karena adanya modifikasi yang substansial pun masih bisa dinilai bukan sebagai pelanggaran hak paten, namun berpengaruh positif terhadap perkembangan

tekonologi negara tersebut. Bukan suatu yang tidak mungkin terjadi, dalam suatu negara terdapat

lebih dari satu pemohon paten atas penemuan-penemuan yang mempunyai

kemiripan satu dan lainnya. Dalam hukum paten dapat terjadi pemohon

pertama yang akan diberikan paten oleh suatu negara, tetapi belum tentu bagi negara lain yang menggunakan aturan atau prinsip "first-to-invent".

Akan tetapi baik first-to-file maupun first-to-invent, keduanya menutup

kemungkinan pihak lainnya yang memiliki kemiripan dengan penemuan

yang telah dipatenkan diterima penemuannya sebagai hak paten. Atas dasar kedua prinsip tersebut, lingkup perlindungan paten dari masingmasing

negara tersebut menjadi penting untuk diketahui. Oleh karena hanya dari aspek lingkup perlindungan yang dimaksud, suatu penemuan baru bisa

diberikan hak paten, sepanjang hasil penemuan tersebut tidak memiliki

kesamaan dengan yang telah didaftarkan sebelumnya menurut prinsip firstto-file atau first-toinvent._Berbagai negara dalam menentukan luas perlindungan paten,

meletakan syarat pada klaimnya dengan sistem yang berbeda. Perlakuan

yang berbeda pada masing-masing negara tersebut, menjadi lebih menarik

apabila dihubungkan dengan pengelompokkan sistem hukum civil law dan common law yang pernah kita dikenal sebelumnya. Dalam sejarah sistem common law yang menolak kodifikasi yang berlaku dalam system civil law, 


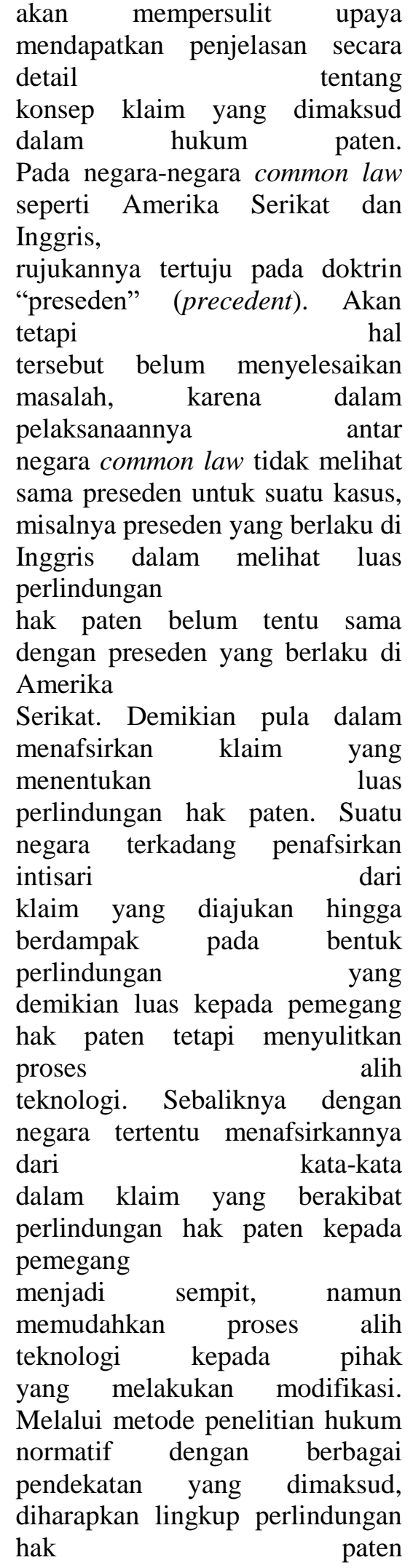

yang berlaku di berbagai negara akan mudah diketahui, minimal hal ini bermanfaat dalam menghindari perang global akibat dominasi ekonomi

melalui penguasaan paten. Demikian, Fred Warshoefskyı mengatakan, saat ini perang global yang terkeji dalam upaya pendominasian ekonomi adalah mengenai hak atas kekayaan intelektual. Saat ini dan masa mendatang

Indonesia akan bertikai terhadap ide, inovasi, kreasi dan penemuanpenemuan. Kancah peperangan bukan di medan perang tapi di forum Pengadilan, yang merenggut jutaan dolar melalui litigasi paten. B. Pembahasan 1. Perlindungan Paten NegaraNegara Eropa Konvensi Paten Eropa, UndangUndang Paten Jerman, Amerika Serikat, dan Jepang, dalam makalah "Comparative Study on the Japanese, the United States and the European Patent Systems", oleh Japan Patent Office Asia-Pacific Industrial Property Center di Jepang belum lama ini (tahun 2001), bila ditelaah banyak mengungkap persamaan/perbedaan perlindungan paten negara-negara tersebut. Beberapa pasal konvensi dan

undang-undang negara dimaksud, memperkaya isi tulisan ini. Walaupun di antara negara-negara Eropa yang menandatangani Konvensi Paten Eropa dan telah menyesuaikan perundangundangan 


\begin{abstract}
nasionalnya, masih terdapat perbedaan penafsiran konsep tentang lingkup perlindungan paten. Seperti ketentuan dalam Pasal 69 ayat (1) Konvensi

Paten Eropa menyebutkan: Theextent of the protection conferred large a European or a European patenapplication shall be determined large theterm of claims. Nevertheless, thedescription and drawings shall be used right interpret the claims. Bagi Belanda hal ini tertuang dalam Pasal $30 \quad$ ayat (2) Undang-Undang Belanda 1986, yang intinya menentukan bahwa yang dilindungi adalah isi klaim, bukan perumusan secara harfiah klaim yang

disertakan dalam permohonan paten suatu penemuan.
\end{abstract}

\section{B. CONCLUSION}

\begin{tabular}{|c|}
\hline $\begin{array}{l}\text { Perbedaan sistem } \\
\text { perlindungan lingkup paten di } \\
\text { berbagai negara, } \\
\text { tidak hanya mengimpor investasi } \\
\text { baru namun juga menentukan } \\
\text { proses } \\
\text { transfer teknologi suatu negara. } \\
\text { Perlindungan yang meluas } \\
\text { menyebabkan } \\
\text { transfer teknologi menjadi tidak } \\
\text { mudah walaupun kurangnya } \\
\text { perlindungan } \\
\text { karena pemilik paten mengalami } \\
\text { kerugian. Kedua perbedaan niat } \\
\text { tersebut mentur studi } \\
\text { menghasilkan perlunya } \\
\text { komparatif tentang cakupan } \\
\text { perlindungan paten } \\
\text { di negara-negara. Ada dua } \\
\text { masalah yang harus dijajaki, }\end{array}$ \\
\hline
\end{tabular}

pertama apa

perbedaan dan kesamaan cakupan perlindungan paten dalam peraturan

negara dan yang kedua bagaimana sistem hukum mempengaruhi kejadian

yang berbeda? Masalah ini akan menggunakan metode penelitian pendekatan statuta menyeluruh dan pendekatan komparatif, pendekatan

kasus, dan pendekatan konseptual. Hasil penelitian menemukan perlindungan paten di negaranegara Eropa, Amerika Serikat, Jepang, dan Indonesia memiliki kesamaan dalam persyaratan proteksi yang mengatur hal baru, langkah inventif, dan penerapan industri. Namun, perlindungan di Amerika Serikat pada awalnya untuk menciptakan sementara basis negara lain berdasarkan berkas pertama. Kemudian ruang lingkup proteksi paten di sana telah ada Jerman menerapkan proteksi terluas, kemudian Amerika

Serikat, dan Jepang, lalu Belanda. Berarti Inggris sebagai negara perlindungan terbatas. Perbedaan proteksi paten dipengaruhi oleh sistem

hukum common law yang lebih mengacu pada precedent daripada civil law dengan kodifikasinya. Jerman adalah satu-satunya negara yang menerapkan

kodifikasi yang kaku terhadap perlindungan paten. Berarti, Indonesia

merumuskan cakupan proteksi paten yang masih terbatas yang terkait 
dengan terbatasnya kasus yang diselesaikan di pengadilan.

C. ACKNOWLEDGEMENT University Of Indonesia University Of Mitra Indonesia Telkom University University Of Mellbourne Saitama University

\section{REFERENCE(Based ISO 690 )}

A. S. Putra And O. M. Febriani,
"Knowledge Management
Online Application In Pdam
Lampung Province," In
Prosiding International
Conference On Information
Technology And Business
(Icitb), 2018, Pp. 181-187.

[2] A. S. Putra, O. M. Febriani, And B. Bachry, "Implementasi Genetic Fuzzy System Untuk Mengidentifikasi Hasil Curian Kendaraan Bermotor Di Polda Lampung," J. Sist. Inf. Dan Manaj. Basis Data, Vol. 1, No. 1, Pp. 21-30, 2018.

[3] O. M. Febriani And A. S. Putra, "Sistem Informasi Monitoring Inventori Barang Pada Balai Riset Standardisasi Industri Bandar Lampung," J. Inform., Vol. 13, No. 1, Pp. 90-98, 2014.

[4] Putra, Arie Setya. "2018 Artikel Struktur Data, Audit Dan Jaringan Komputer." (2018).

[5] Putra, A. S. (2018, July 17). Paperplain Fundamental Create Application With Borland
Delphi 7.0 University Of Mitra Indonesia. Retrieved From Osf.Io/Pb

\section{E. REFERENCE $($ Based APA )}

Putra, A. S., Aryanti, D. R., \& Hartati, I. (2018, November). Metode SAW (Simple Additive Weighting) sebagai Sistem Pendukung Keputusan Guru Berprestasi (Studi Kasus: SMK Global Surya). In Prosiding Seminar Nasional Darmajaya (Vol. 1, No. 1, pp. 85-97).

Sari, D. P., Febriani, O. M., \& Putra, A. S. (2018, November). Perancangan Sistem Informasi SDM Berprestasi pada SD Global Surya. In Prosiding Seminar Nasional Darmajaya (Vol. 1, No. 1, pp. 289-294).

Putra, A. S. (2018). Paperplain: Execution Fundamental Create Application With Borland Delphi 7.0 University Of Mitra Indonesia.

Putra, A. S., Sukri, H., \& Zuhri, K. Sistem Monitoring Realtime Jaringan Irigasi Desa (JIDES) Dengan Konsep Jaringan Sensor Nirkabel. IJEIS (Indonesian Journal of Electronics and Instrumentation Systems), 8(2), 221232.

Darmawan, A., Yuliawati, D., Marcella, O., \& Firmandala, R. (2016). Sistem Absensi dan Pelaporan Berbasis Fingerprint dan SMS Gateway. EXPLORE, 7(1).

Febriani, O. M., Wahyuni, T., \& Yusuf, S. (2017). DESIGN OF WEBSITE-BASED INFORMATION 
SYSTEM FOR EDOCUMENT

ADMINISTRASI IN THE

COMMUNITY SERVICE UNIT (A

Case Study at Rajabasa District).

INTERNATIONAL JOURNAL OF COMPUTERS \& TECHNOLOGY, 16(7), 7010-7020.

Febriani, O. M., \& Wahyuni, T. (2017, October). PERANCANGAN SISTEM E-DOCUMENT ADMINISTRASI LOGBOOK PENELITIAN PADA UNIT LAYANAN DI BANDAR LAMPUNG. In Prosiding Seminar Nasional Darmajaya (Vol. 1, No. 1, pp. 187-194).

Febriani, O. M., \& Permadi, A. B. (2017). Implementasi Sistem Aplikasi Data Bimbingan dan Pelanggaran Siswa pada Sekolah Menengah Atas di Lampung Tengah dengan Metode Analisis dan Desain Sistem Terdistribusi (SSAD). EXPERT, 7(1).

Febriani, O. M., \& Ambarwati, L. (2015). PERANCANGAN APLIKASI PENGOLAHAN DATA PENJUALAN UKM KELANTING KHAS TELO DESA SIDOHARJO KECAMATAN JATI AGUNG KABUPATEN LAMPUNG SELATAN. Jurnal Teknologi Informasi dan Bisnis Pengabdian Masyarakat Darmajaya, 1(1), 77-95.

Febriani, O. M. (2015). Rancang Bangun Aplikasi Ecommercemenggunakan Freewebstore pada UKM Kelanting di Desa Sidoharjo Lampung Selatan. Prosiding Sembistek 2014, 1(02), 446-458. 